\title{
PENGARUH KARAKTER EKSEKUTIF, KOMPENSASI RUGI FISKAL DAN CAPITAL INTENSITYTERHADAP PENGHINDARAN PAJAK
}

(Studi Empiris pada Perusahaan Sektor Industri Barang Konsumsi yang Terdaftar di Bursa Efek Indonesia Tahun 2016-2020)

\author{
Ayu Safitri ${ }^{1}$ \\ Wiwit Irawati ${ }^{2}$ \\ Program Studi Akuntansi S1, Fakultas Ekonomi dan Bisnis, Universitas Pamulang \\ Email: ayusafitri407@gmail.com ${ }^{1}$; wiwitira@unpam.ac.id ${ }^{2}$
}

\begin{abstract}
The research was intended to analyze the impact of the executive character, fiscal loss compensation and capital intensity against tax avoidance. This type of research is an assosiative quantitative using secondary data populations obtained from the Indonesian stock exchange and the 2016-2020 period company website of 23 companies. The sample retrieval technique on this study is by using purposive sampling method with the data analysis used is the regression data panel analysis by selecting the regression model, classic assumptions test and hypothetical analysis using data processing program Eviews 10. Based on the result of the test, the sudy states that: based on test of the executive character, fiscal loss compensation and capital intensity are simultaneously take effect by tax avoidance. Whereas by test $T$ (partial) fiscal loss compensation affect tax avoidance, while executive character and capital intensity do not take affect tax avoidance.
\end{abstract}

Keywords: executive character, fiscal loss compensation, capital intensity, tax avoidance

\begin{abstract}
ABSTRAK
Penelitian ini bertujuan untuk menguji pengaruh karakter eksekutif, kompensasi rugi fiskal dan capital intensity terhadap penghindaran pajak. Jenis penelitian ini adalah kuantitatif asosiatif dengan menggunakan populasi data sekunder yang diperoleh dari Bursa Efek Indonesia, dan website perusahaan periode tahun 2016-2020 yang berjumlah 23 perusahaan. Teknik pengambilan sampel pada penelitian ini adalah menggunakan metode pertimbangan tertentu sehingga menjadi balanced panel data dengan teknik analisis data yang digunakan adalah analisis regresi data panel dengan memilih model regresi, uji asumsi klasik dan analisa hipotesis dengan menggunakan olah data program Eviews 10. Berdasarkan hasil uji, penelitian ini menyatakan bahwa: berdasarkan uji $F$ karakter eksekutif, kompensasi rugi fiskal, capital intensity secara simultan berpengaruh terhadap penghindaran pajak, sedangkan melalui uji t (parsial) kompensasi rugi fiskal berpengaruh terhadap penghindaran pajak, sedangkan karakter eksekutif dan capital intensity secara parsial tidak berpengaruh terhadap penghindaran pajak.
\end{abstract}

Kata kunci: karakter eksekutif, kompensasi rugi fiskal, capital intensity, penghindaran pajak 


\section{PENDAHULUAN}

\section{Latar Belakang}

Menurut UU No 28 Tahun 2007 Pajak adalah kontribusi wajib kepada negara yang terutang oleh orang pribadi atau badan yang bersifat memaksa berdasarkan UndangUndang, dengan tidak mendapatkan imbalan secara langsung dan digunakan untuk keperluan negara bagi sebesar-besarnya kemakmuran rakyat. Pembayaran pajak merupakan perwujudan dari kewajiban kenegaraan dan peran serta wajib pajak untuk secara langsung dan bersama-sama melaksanakan kewajiban perpajakan untuk pembiayaan negara dan pembangunan nasional. Sesuai falsafah undang-undang perpajakan, membayar pajak bukan hanya merupakan kewajiban, tetapi merupakan hak dari setiap warga negara untuk ikut berpartisipasi dalam bentuk peran serta terhadap pembiayaan negara dan pembangunan nasional (Pajak.go.id). Pajak sangat penting bagi negara, tetapi dari sudut pandang perusahaan, pajak merupakan salah satu komponen biaya yang mengurangi laba perusahaan. Beban pajak yang tinggi mendorong banyak perusahaan berusaha melakukan manajemen pajak agar pajak dibayarkan lebih sedikit (Ulfa, 2018).

Ada beberapa fenomena penghindaran pajak contohnya kasus penghindaran pajak pada tahun 2018 terdapat sebuah perusahaan yang bergerak dibidang elektronik di Korea, yakni Samsung Electronics. Pemimpin Samsung Electronics ditetapkan sebagai tersangka kasus penghindaran pajak senilai 8,2 miliar won atau sekitar Rp102 miliar. Presiden Samsung Lee Kun Hee dan seorang eksekutif perusahaan itu mengelola dana di 260 rekening bank yang menggunakan nama 72 pejabat eksekutif dan dicurigai menghindari pembayaran pajak senilai 8,2 miliar won. Polisi menambahkan ratusan rekening bank itu berisi dana sebesar 400 juta won. Rekening-rekening tersebut ditemukan dalam penyelidikan terkait masalah pembayaran renovasi kediaman keluarga Lee. Penyelidikan ini membuka kembali kasus keterlambatan pembayaran pajak senilai 130 miliar won, atau sekitar Rp 1,6 triliun, pada tahun 2011. Namun, hanya 8,2 miliar won yang masih bisa diperkarakan. Penghindaran pajak 2011 itu berujung pada penahanan Jay Y. Lee, putra Lee, pada tahun 2017 dan mendasari jatuhnya mantan presiden Korea Selatan (Korsel) Park Geun Hye. Samsung pun akhinya memberikan otoritas lebih besar bagi jajaran manajemen tingginya untuk mengurangi pengaruh keluarga Lee. Pada tahun 2009, Lee juga pernah diselidiki karena penghindaran pajak dan penggunaaan rekening bank atas nama orang lain. Dia diputus bersalah pada 2009, tapi kemudian mendapat pengampunan (Annisa, 2018). 
Kemudian, kasus penghindaran pajak yang terjadi di Indonesia adalah Google. Pemerintah Indonesia sedang berusaha mengejar pajak Google. Untuk 2015 saja, raksasa internet asal Amerika Serikat (AS) ini harus membayar pajak lebih dari US\$ 400 juta atau setara dengan Rp 5,2 triliun bila terbukti melakukan penghindaran pajak di Tanah Air. Ternyata, Google tidak hanya berusaha menghindari pajak di Indonesia. Di negara lain, Alphabet Inc, induk perusahaan Google, juga melakukan upaya-upaya untuk menghindari pajak. Kasus serupa Indonesia terjadi di Inggris, Prancis, Italia, dan Spanyol. Menteri Keuangan Sri Mulyani, menyatakan Google harus mengikut peraturan pajak yang berlaku, karena mendapatkan keuntungan dari aktivitas ekonomi Indonesia. Sama halnya dengan jutaan wajib pajak lainnya (Baskoro, 2016).

Fenomena lain penghindaran pajak juga diduga dilakukan oleh perusahaan multinasional, salah satunya perusahaan tembakau milik British American Tobacco (BAT) diduga melakukan penghindaran pajak (tax avoidance) di Indonesia melalui PT. Bentoel Internasional Ivestama Tbk (RMBA). Praktik tersebut diperkirakan menimbulkan kerugian negara sebesar US \$14 juta per tahun. Dugaan Kecurangan ini merupakan hasil penelusuran lembaga Tax Justice Network (TJN). TJN adalah lembaga independen berjaringan internasional berkantor pusat di London, Inggris yang fokus melakukan penelitian dan kajian terkait kebijakan serta pelaksanaan perpajakan. Menurut laporan dari Lembaga Tax Justice Network perusahaan tembakau milik British American Tobacco (BAT) melakukan penghindaran pajak melalui PT Bentoel Internasional Investama dengan cara banyak mengambil pinjaman antara tahun 2013 dan 2015 dari perusahaan afiliasi di Belanda yaitu Rothmans Far East BV untuk pembiayaan ulang utang bank serta membayar mesin dan peralatan. Pembayaran bunga yang dibayarkan akan mengurangi penghasilan kena pajak di Indonesia, sehingga pajak yang dibayarkan menjadi lebih sedikit akibatnya negara bisa menderita kerugian US \$14 juta pertahun (Kontan.co.id, 2019).

Pohan (2017) menjelaskan bahwa penghindaran pajak adalah strategi dan teknik penghindaran pajak yang dilakukan secara aman bagi wajib pajak karena tidak bertentangan dengan ketentuan perpajakan. Metode dan teknik yang digunakan cenderung memanfaatkan kelemahan-kelemahan (grey area) yang terdapat dalam undang-undang dan peraturan perpajakan itu sendiri untuk memperkecil jumlah pajak yang terutang. Penghindaran pajak kurang disukai oleh pemerintahan karena berdampak langsung untuk mengurangi beban pajak, sehingga hal ini akan mengakibatkan berkurangnya pemasukan negara (Setiawan, 2019). 
Maysaroh (2017) menyatakan terdapat beberapa faktor yang mempengaruhi sebuah perusahaan dalam memenuhi kewajiban perpajakannya. Faktor pertama yaitu Karakter Eksekutif. Karakter eksekutif yang berperan sebagai pemimpin sebuah perusahaan memiliki pengaruh terhadap penghindaran pajak. Pemimpin perusahaan yang menduduki posisi teratas baik sebagai top eksekutif maupun top manajer dalam memberikan arahan serta menjalankan kegiatan usaha sesuai dengan tujuan yang ingin dicapai perusahaan, di mana setiap pimpinan memiliki karakter yang berbeda-beda. Karakter eksekutif yang bersifat risk taker akan lebih berani mengambil risiko dalam berbisnis untuk memiliki penghasilan, posisi, kesejahteraan, dan kewenangan yang lebih tinggi dalam memperoleh keuntungan. Sedangkan karakter eksekutif yang bersifat risk averse merupakan eksekutif yang cenderung tidak mempunyai risiko sehingga kurang berani mengambil keputusan dalam berbisnis. Maka karakter eksekutif yang bersifat risk taker akan semakin tinggi tingkat penghindaran pajak tax avoidance (Maisyaroh, 2016).

Faktor yang kedua adalah kompensasi kerugian fiskal (carrying loss), sesuai dengan Undang-Undang Nomor 36 tahun 2008 kompensasi kerugian fiskal merupakan suatu proses pembawa kerugian dalam satu tahun pajak ke tahun-tahun pajak berikutnya, Kerugian tersebut dapat dikompensasikan selama lima tahun ke depan dan laba perusahaan akan digunakan untuk mengurangi jumlah kompensasi tersebut. Sehingga, laba kena pajak akan digunakan untuk mengurangi jumlah kompensasi kerugian perusahaan.

Faktor yang ketiga adalah capital intensity. Capital intensity dapat di definisikan sebagai seberapa besar perusahaan menginvestaskan asetnya pada aset tetap dan persediaan (Sugiarto, 2019). Menurut Wiguna (2017) menjelaskan bahwa capital intensity didefinisikan sebagai seberapa besar perusahaan yang menginvestasikan kekayaannya pada aset tetap. Aset tetap dapat dimanfaatkan oleh perusahaan untuk melakukan penghindaran pajak agar Effective Tax Rate (ETR) perusahaan rendah. Hal ini menunjukan bahwa semakin tinggi capital intensity menyebabkan semakin tinggi pula penghindaran pajak yang dilakukan perusahaan. Sehingga perusahaan dapat memanfaatkan beban penyusutan dari aset tetap yang secara langsung mengurangi laba perusahaan yang menjadi dasar perhitungan pajak perusahaan.

Berdasarkan hal yang telah dikemukakan sebelumnya, maka penelitian ini bermaksud untuk melihat peran Karakter Eksekutif, Kompensasi Rugi Fiskal dan Capital Intensity terhadap Penghindaran Pajak. Penelitian ini ingin membuktikan dan mempertegas hasil penelitian terdahulu yang masih belum konsisten seperti penelitian yang dilakukan oleh Sopyanto (2018) yang menyatakan bahwa Karakter Eksekutif tidak 
berpengaruh signifikan terhadap penghindaran pajak. Sedangkan penelitian yang dilakukan Lerid et Al., (2020) dan Geminiasti (2017) menunjukan hasil bahwa karakter eksekutif berpengaruh terhadap penghindaran pajak. Penelitian yang dilakukan oleh Humairoh dan Triyanto (2019) menunjukan hasil bahwa kompensasi rugi fiskal tidak berpengaruh terhadap penghindaran pajak. Sedangkan hasil penelitian yang dilakukan Ginting (2016) menunjukan bahwa kompensasi rugi fiskal berpengaruh signifikan terhadap penghindaran pajak. Untuk variabel Capital Intensity dari hasil penelitian yang dilakukan oleh Setiawan (2019) disimpulkan bahwa variabel Capital Intensity berpengaruh terhadap penghindaran pajak dengan pengaruh positf yang berlawanan dengan hasil penelitian yang dilakukan oleh Firman (2017) bahwa variabel Capital Intensity tidak berpengaruh signifikan terhadap penghindaran pajak.

\section{Tujuan Penelitian}

Sesuai dengan latar belakang dan rumusan masalah yang telah diuraikan sebelumnya, maka tujuan dari penelitian ini adalah: (1) Untuk menguji dan memberi bukti empiris pengaruh Karakter Eksekutif, Kompensasi Rugi Fiskal dan Capital Intensity terhadap Penghindaran Pajak. (2) Untuk menguji dan memberi bukti empiris pengaruh Karakter Eksekutif terhadap Penghindaran Pajak. (3) Untuk menguji dan memberi bukti empiris pengaruh Kompensasi Rugi Fiskal terhadap Penghindaran Pajak. (4) Untuk menguji dan memberi bukti empiris pengaruh Capital Intensity terhadap Penghindaran Pajak.

\section{TINJAUAN PUSTAKA}

\section{Teori Keagenan}

Jansen dan Meckling (1976) menyatakan teori agensi adalah teori yang menyatakan adanya hubungan antara pihak yang memberi wewenang (principal) dan pihak yang menerima wewenang (agent). Teori ini muncul karena adanya hubungan antara principal dan agent. Teori agensi mengasumsikan bahwa semua individu bertindak atas kepentingan mereka sendiri. Pemegang saham sebagai principal diasumsikan hanya tertarik kepada hasil keuangan atau investasi mereka yang bertambah di dalam perusahaan sedangkan agen diasumsikan cenderung berkeinginan untuk menerima kepuasan berupa kompensasi keuangan maupun fasilitas lainnya yang lebih besar (Irawati \& Sari, 2019). Luayyi (2010) menyebutkan bahwa di dalam teori keagenan pada dasarnya membahas suatu bentuk kesepakatan antara pemilik modal dan manajer untuk mengelola suatu perusahaan, di sini manajer mengemban tanggung 
jawab yang besar atas keberhasilan operasi perusahaan yang dikelolanya, jika dalam menjalankan amanah tersebut manajer gagal maka jabatan dan segala fasilitas yang diperoleh nya menjadi taruhannya, alasan itulah yang sering kali mendasari mengapa manajer mau melakukan penghindaran pajak.

\section{Pengembangan Hipotesis}

\section{Pengaruh Karakter Eksekutif, Kompensasi Rugi Fiskal, Capital Intensity terhadap Penghindaran Pajak}

Keputusan untuk melakukan penghindaran pajak bergantung pada individu eksekutif perusahaan. Penelitian Merkusiwati dan Damayanthi (2019) menyatakan bahwa eksekutif yang berani mengambil risiko atau disebut sebagai risk takerakan lebih memiliki pengaruh terhadap penghindaran pajak dibandingkan dengan eksekutif yang tidak berani mengambil risiko risk averse. Pernyatan tersebut juga didukung oleh penelitian yang dilakukan oleh Sopyanto (2018), Malinda (2017) yang menjelaskan bahwa semakin eksekutif bersifat risk taker, semakin tinggi tingkat penghindaran pajak yang dilakukan perusahaan.

Menurut Ginting (2016) Kompensasi kerugian dalam pajak penghasilan dapat dikompensasikan selama lima tahun ke depan dan laba perusahaanakan digunakan untuk mengurangi jumlah kompensasi kerugian tersebut. Akibatnya, selama lima tahun tersebut, perusahaan akan terhindar dari beban pajak, karena laba kena pajak akan digunakan untuk mengurangi jumlah kompensasi kerugian perusahaan. Berdasarkan uraian di atas, dirumuskan hipotesis penelitian.

Kepemilikan aset tetap dapat mengurangi pembayaran pajak yang dibayarkan perusahaan. Karena adanya biaya depresiasi yang melekat pada aset tetap. Biaya depresiasi dapat dimanfaatkan oleh manajer untuk meminimumkan pajak yang dibayar perusahaan. Bahwa semakin tinggi capital intensity ratio yang dimiliki perusahaan maka memiliki ETR yang rendah. Pernyataan tersebut juga didukung oleh penelitian yang dilakukan oleh Setiawan (2019), Merkusiwati dan Damayanthi (2019), Sopyanto (2018), serta Firman (2017) yang menemukan capital intensity berpengaruh positif pada penghindaran pajak. Berdasarkan penjabaran di atas dapat dirumuskan hipotesis sebagai berikut:

H1: Diduga karakter eksekutif, kompensasi rugi fiskal dan capital intensity berpengaruh terhadap Penghindaran Pajak. 


\section{Pengaruh Karakter Eksekutif terhadap Penghindaran Pajak}

Penelitian Merkusiwati dan Damayanthi (2019) menyatakan teori keagenan berkaitan dengan penyelesaian masalah yang dapat terjadi dalam hubungan keagenan, salah satunya masalah risiko yang muncul ketika principaldan agentmemiliki pandangan yang berbeda terhadap risiko. Masalah yang terjadi bahwa principal dan agent dapat memilih tindakan yang berbeda karena preferensi risiko yang berbeda. Posisi, peran serta tujuan principal dan agent yang berbeda tersebut akan mengakibatkan konflik kepentingan.

Keputusan untuk melakukan penghindaran pajak bergantung pada individu eksekutif perusahaan. Penelitian Merkusiwati dan Damayanthi (2019) menyatakan bahwa eksekutif yang berani mengambil risiko atau disebut sebagai risk takerakan lebih memiliki pengaruh terhadap penghindaran pajak dibandingkan dengan eksekutif yang tidak berani mengambil risiko risk averse. Pernyatan tersebut juga didukung oleh penelitian yang dilakukan oleh Sopyanto (2018), Malinda (2017) yang menjelaskan bahwa semakin eksekutif bersifat risk taker, semakin tinggi tingkat penghindaran pajak yang dilakukan perusahaan. Oleh karena itu, hipotesis kedua ini adalah sebagai berikut: H2: Diduga Karakter eksekutif berpengaruh pada Penghindaran Pajak

\section{Pengaruh Kompensasi Rugi Fiskal terhadap Penghindaran Pajak}

Menurut teori agensi mengenai perbedaan kepentingan antara principa/dan agent dalam kebijakan pajak perushaan selain mendorong manajer melakukan intensitas modal untuk mengurangi beban pajak, juga mendorong manajer melakukan cara lain seperti melakukan kompensasi kerugian fiskal perushaan untuk meminimalisir beban pajak perusahaan. Perusahaan yang telah merugi dalam satu periode akuntansi diberikan keringanan untuk membayar pajaknya. Proses membawa kerugian dalam satu tahun pajak ke tahun-tahun pajak berikutnya dinamakan dengan kompensasi kerugian (carrying lost). Kompensasi kerugian dalam pajak penghasilan diatur pada UndangUndang No. 36 Tahun 2008 Pasal 6 ayat (2) tentang pajak penghasilan.

Menurut Ginting (2016) Kerugian tersebut dapat dikompensasikan selama lima tahun ke depan dan laba perusahaan akan digunakan untuk mengurangi jumlah kompensasi kerugian tersebut. Akibatnya, selama lima tahun tersebut, perusahaan akan terhindar dari beban pajak, karena laba kena pajak akan digunakan untuk mengurangi jumlah kompensasi kerugian perusahaan. Pernyatan tersebut juga didukung oleh penelitian yang dilakukan oleh Arini (2017) yang menjelaskan bahwa Kompensasi Rugi Fiskal berpengaruh positif terhadap penghindaran pajak, perusahaan yang memiliki 
kompensasi rugi fiskal di tahun t maka tentu saja itu akan mengurangi beban pajaknya pada tahun tersebut, dan itu menjadi kesempatan bagi perusahaan untuk melakukan penghindaran pajak. Berdasarkan penjelasan di atas, maka hipotesis ketiga yang akan diuji dalam penelitian ini adalah:

H3: Diduga Kompensasi rugi fiskal berpengaruh terhadap Penghindaran Pajak

\section{Pengaruh Capital Intensity terhadap Penghindaran Pajak}

Capital Intensity adalah seberapa besar perusahaan menginvestasikan asetnya dalam bentuk aset tetap dan persediaan (Sugiarto, 2019). Berdasarkan teori agensi, perbedaan kepentingan antara principal dan agent dapat mempengaruhi berbagai hal yang menyangkut kinerja perusahaan, salah satunya adalah kebijakan perusahaan mengenai pajak. Pihak principa/ tentu menginginkan laba perusahaan yang besar, hal itu membuat agentmelakukan tindakan Intensitas modal guna memperkecil beban pajak perusahaan. Di mana dalam prakteknya akan meningkatkan investasi perusahaan terhadap aset tetapnya.

Kepemilikan aset tetap dapat mengurangi pembayaran pajak yang dibayarkan perusahaan. Karena adanya biaya depresiasi yang melekat pada aset tetap. Biaya depresiasi dapat dimanfaatkan oleh manajer untuk meminimumkan pajak yang dibayar perusahaan. Bahwa semakin tinggi capital intensity ratio yang dimiliki perusahaan maka memiliki ETR yang rendah. Pernyataan tersebut juga didukung oleh penelitian yang dilakukan oleh Setiawan (2019), Merkusiwati dan Damayanthi (2019), Sopyanto (2018), serta Firman (2017) yang menemukan capital intensity berpengaruh positif pada penghindaran pajak.

Berdasarkan penjelasan di atas, maka hipotesis keempat yang akan diuji dalam penelitian ini adalah:

H4: Diduga Capital intensity berpengaruh terhadap Penghindaran Pajak

\section{METODE PENELITIAN}

\section{Jenis Penelitian}

Penelitian ini menggunakan jenis penelitian kuantitatif dan menggunakan metode asosiatif. Menurut Sugiyono (2017), metode penelitian kuantitatif adalah metode penelitian yang berlandaskan pada filsafat positivisme, digunakan untuk meneliti pada populasi atau sampel tertentu, pengumpulan data menggunakan instrument penelitian, analisis data bersifat kuantitatif atau statistik, dengan tujuan untuk menguji hipotesis yang telah ditetapkan. Sedangkan asosiatif adalah penelitian yang bertujuan untuk 
mengetahui hubungan antara dua variable atau lebih. Terdapat tiga bentuk hubungan yaitu hubungan simetris, hubungan kasual, dan interaktif/resprocal/timbal balik.

\section{Tempat dan Waktu Penelitian}

Untuk memperoleh data sehubungan dengan masalah yang akan diteliti dalam penelitian ini peneliti menggunakan data sekunder. Sumber data yang digunakan dalam penelitian ini adalah pengambilan data perusahaan industri barang konsumsi tahun 2016-2020 yang diambil dari Bursa Efek Indonesia. Alasan pemilihan tahun yang digunakan adalah untuk mendapatkan hasil yang lebih akurat sesuai dengan keadaan sekarang. Sumber data diambil dari Bursa Efek Indonesia karena Bursa Efek Indonesia menyediakan laporan keuangan perusahaan yang sudah go public. Laporan keuangan perusahaan yang sudah go public dapat dipercaya karena telah diaudit oleh auditor publik.

\section{Variabel Dependen ( $Y$ )}

\section{Penghindaran Pajak}

Penghindaran pajak dalam penelitian ini diproksikan menggunakan rasio Effective Tax Rates (ETR). ETR dalam penelitian ini hanya menggunakan model utama yang digunakan Putri dan Irawati (2019), yaitu beban pajak penghasilan di bagi dengan pendapatan sebelum pajak perusahaan. Semakin baik nilai ETR ditandai dengan semakin rendahnya nilai ETR perusahaan tersebut. Semakin rendah nilai ETR maka perusahaan semakin tinggi tingkat penghindaran pajaknya (Putri \& Irawati, 2019). Sebagai rumus untuk menghitung ETR adalah sebagai berikut:

\section{Beban Pajak \\ $\mathbf{E T R}=$ \\ Laba sebelum pajak (EBIT)}

\section{Variabel Independen}

\section{Karakter Eksekutif (X1)}

Karakter eksekutif dibedakan menjadi dua yaitu risk taker atau risk averse yang tercermin dari besar kecilnya risiko perusahaan (Leris, Sianturi, \& Pratomo, 2020). Untuk mengetahui karakter eksekutif maka digunakan risiko perusahaan (corporate risk) yang dimiliki perusahaan. Risiko perusahaan mencerminkan penyimpangan atau deviasi standar dari earning. Baik penyimpangan itu bersifat kurang dari yang direncanakan atau mungkin lebih dari yang direncanakan. Untuk mengukur risiko perusahaan ini dihitung 
melalui standar deviasi dari EBITDA (earning before interest, tax, depreciation, and amortization) dibagi dengan total aset perusahaan (Sopyanto, 2018). Rasio risiko perusahaan dapat diukur menggunnakan rumus sebagai berikut:

\section{Risiko Perusahaan $=\frac{\text { EBITDA }}{\text { TotalAset }}$}

\section{Kompensasi Rugi Fiskal (X2)}

Proses membawa kerugian dalam satu tahun pajak ke tahun-tahun pajak berikutnya dinamakan dengan kompensasi kerugian (Carrying loss). Kompensasi kerugian dalam Pajak Penghasilan diatur pada Undang-Undang No.36 Tahun 2008 pasal 6 ayat 2 tetang Pajak Penghasilan. Kompensasi rugi fiskal diduga dapat dimanfaatkan perusahaan untuk melakukan penghindaran pajak. Kompensasi rugi fiskal dapat diukur dengan skala nominal yaitu nilai 1 diberikan jika terdapat kompensasi rugi fiskal pada awal tahun $\mathrm{t}$ dan nilai 0 diberikan jika tidak terdapat kompensasi rugi fiskal pada awal tahun $\mathrm{t}$.

\section{Capital Intensity (X3)}

Dalam penelitian ini capital intensity diproksikan menggunakan rasio intensitas aset tetap. Intensitas aset tetap adalah seberapa besar aset tetap yang dimiliki perusahaan dengan total aset perusahaan. Manajemen akan memanfaatkan penyusutan aset tetap untuk menekan beban pajak perusahaan. Dengan adanya biaya penyusutan akibat dari depresiasi aset tetap menghasilkan biaya yang langsung dapat mengurangi laba perusahaan. Sehingga mengakibatkan perusahaan membayar pajak dengan jumlah yang rendah (Pranyoto, 2017). Ratio intensitas aset tetap dapat diukur menggunakan rumus sebagai berikut:

$$
\text { Capital Intensity Ratio }=\frac{\text { Total Aset Tetap }}{\text { TotalAset }}
$$

\section{Populasi dan Sampel Penelitian}

Populasi yang digunakan dalam penelitian ini adalah industri barang konsumsi yang terdaftar dalam Bursa Efek Indonesia periode 2016-2020. Alasan memilih perusahaan yang bererak di perusahaan sektor industri barang konsumsi, karena perusahaan yang bergerak di bidang ini cukup diminati oleh para investor sebab telah dibuktikan melalui daya tahan sektor konsumer yang tumbuh $28 \%$, kenaikan ini 
merupakan kenaikan tertinggi kedua dari sembilan sektor yang ada (www.kemenperin.go.id). Sampel dalam penelitian ini menggunakan kriteria-kriteria yang telah ditentukan sebelumnya dengan hasil sebagai berikut:

Tabel 1. Tahapan Seleksi Sampel Berdasarkan Kriteria

\begin{tabular}{|c|c|c|c|}
\hline No. & Kriteria & $\begin{array}{l}\text { Pelanggaran } \\
\text { Kriteria }\end{array}$ & Jumlah \\
\hline 1 & $\begin{array}{l}\text { Perusahaan industri barang konsumsi yang } \\
\text { terdaftar dalam Bursa Efek Indonesia (BEI) selama } \\
\text { periode tahun } 2016-2020 \\
\text { Perusahaan vana memnublikasikan lanoran }\end{array}$ & & 67 \\
\hline 2 & $\begin{array}{l}\text { keuangan dan yang telah diaudit berturut-turut } \\
\text { selama periode } 2016-2020 \\
\text { Perusahaan yang datanya tidak mencantumkan }\end{array}$ & (28) & 39 \\
\hline 3 & $\begin{array}{l}\text { Rupiah (Rp) sebagai mata uangnya pada tahun } \\
2016-2020\end{array}$ & (0) & 39 \\
\hline 4 & $\begin{array}{l}\text { Perusahaan yang datanya tidak mendukung dan } \\
\text { tidak sesuai dengan kriteria variabel yang diteliti } \\
\text { pada tahun } 2016-2020\end{array}$ & $(16)$ & 23 \\
\hline & Total Sampel & & 23 \\
\hline & Tahun Pengamatan & & 5 \\
\hline & Jumlah Data & & 115 \\
\hline
\end{tabular}

\section{Teknik Pengumpulan Data}

Berdasarkan teknik pemgumpulan data yang bertujuan mencari informasi yang sesuai dengan permasalahan penelitian ini, maka teknik pengumpulan data yang digunakan sebagai berikut: (1) Dokumentasi. Dengan cara mengumpulkan, mencatat, mengunduh dan mengolah data sekunder berupa laporan keuangan tahunan dari perusahaan yang terdaftar di BEI. Di mana laporan keuangan tahunan diperoleh melalui website resmi Bursa Efek Indonesia (BEI), yaitu www.idx.co.id dan website perusahaan. (2) Studi Pustaka. Suatu penelitian yang bersifat teoritis, dimana penelitian ini deilakukan dengan cara pengumpulan data dan membaca serta mempelajari data tersebut. Serta membaca pendapat yang dikemukakan oleh para ahli yang telah meneliti hal yang berkaitan dengan permasalahan yang akan di teliti, untuk memperoleh landasan teori yang dapat menunjang penelitian ini. (3) Studi Internet. Terkadang buku referensi yang dimiliki dan literatur yang ada serta buku pinjaman dari perpustakaan telah menyimpan informasi yang sudah kadaluarsa dengan kata lain informasi tersebut tidak berdasarkan hal yang baru. Karena suatu ilmu akan selalu berkembang disetiap masa nya dengan pesat, peneliti menggunakan jaringan internet untuk memperoleh informasi yang lebih terbaru, agar teori yang disajikan adalah teori yang terup to date. 


\section{Metode Analisis Data}

Teknik analisis data pada penelitian ini meliputi, uji asumsi klasik yang terdiri dari uji normalitas, uji multikoliniearitas, uji heterokedastisitas, uji autokorelasi. Dan dilanjutkan dengan uji deskripstif, uji data panel dengan model regresi linear berganda, uji hipotesis, uji F (simulta), uji-t (parsial) dan uji koefisien determinasi. Pengelolaan data pada penelitian ini menggunakan perangkat lunak (software) E-views 10.

\section{HASIL PENELITIAN}

\section{Hasil Uji Asumsi Klasik}

\section{Uji Normalitas}

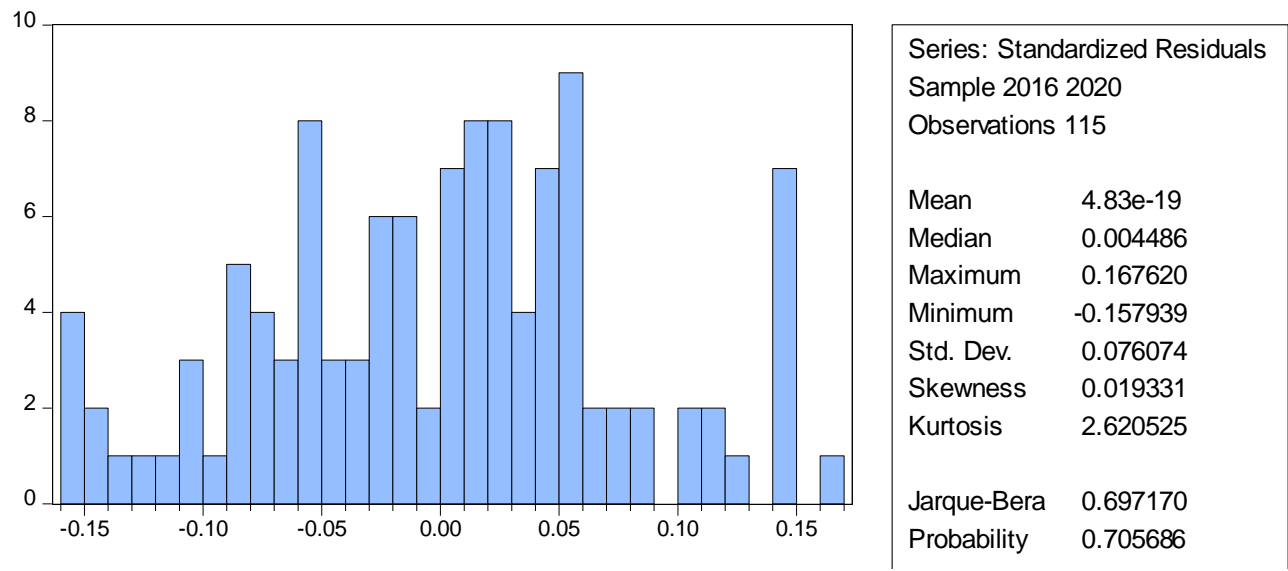

Sumber: Data diolah dengan Eviews 10, 2021

\section{Gambar 1 Uji Normalitas}

Nilai probablilitas nya 0.7056 lebih besar dari signifikasi alpha 5\% (0.05). Dengan demikian dapat disimpulkan bahwa data berdistribusi normal yang berarti model regresi telah memenuhi asumsi normalitas.

\section{Uji Multikolonieritas}

Tabel 2. Uji Multikolonieritas

\begin{tabular}{cccc}
\hline \hline Variable & $\begin{array}{c}\text { Coefficient } \\
\text { Variance }\end{array}$ & $\begin{array}{c}\text { Uncentered } \\
\text { VIF }\end{array}$ & $\begin{array}{c}\text { Centered } \\
\text { VIF }\end{array}$ \\
\hline C & 0.001112 & 9.902771 & NA \\
Karakter Eksekutif & 0.029320 & 1.910375 & 1.021222 \\
Kompensasi Rugi Fiskal & 0.000658 & 1.324755 & 1.025246 \\
Capital Intensity & 0.006498 & 8.635283 & 1.006294 \\
\hline \hline
\end{tabular}

Sumber: Data diolah dengan Eviews 10, 2021

Nilai VIF semua variabel tersebut memperoleh nilai VIF yang lebih kecil dari 10 , sehingga dalam uji tersebut tidak terjadi multikolinieritas antar variabel bebas terhadap model regresi. 


\section{Uji Heteroskedastistas}

\section{Tabel 3. Uji Heteroskedastistas}

Heteroskedasticity Test: White

\begin{tabular}{llll}
\hline \hline F-statistic & 0.922923 & Prob. F(8,106) & 0.5008 \\
Obs* S-squared $_{\text {Scaled explained SS }}$ & 7.488653 & Prob. Chi-Square(8) & 0.4849 \\
& 64.79608 & Prob. Chi-Square(8) & 0.0000 \\
\hline
\end{tabular}

Sumber: Data diolah dengan Eviews 10, 2021

Nilai probabilitas yang dihasilkan ialah sebesar 0.4849 lebih besar dari nilai alpha $5 \%$. Dengan demikian dapat disimpulkan bahwa tidak terjadi heteroskedastistas dalam model regresi.

\section{Uji Autokorelasi}

Tabel 4. Uji Autokorelasi

\begin{tabular}{lllr}
\hline \hline R-squared & 0.129278 & Mean dependent var & $6.54 \mathrm{E}-17$ \\
Adjusted R-squared & 0.089337 & S.D. dependent var & 0.112112 \\
S.E. of regression & 0.106987 & Akaike info criterion & -1.581464 \\
Sum squared resid & 1.247627 & Schwarz criterion & -1.438250 \\
Log likelihood & 96.93417 & Hannan-Quinn criter. & -1.523334 \\
F-statistic & 3.236704 & Durbin-Watson stat & 1.962200 \\
Prob(F-statistic) & 0.009180 & & \\
\hline \hline
\end{tabular}

Sumber: Data diolah dengan Eviews 10, 2021

Nilai statstik Durbin Waston berada di wilayah tidak ada autokorelasi dikarenakan nilai Durbin Waston sebesar 1.962200 terletak diantara du dan 4-du $(1.7496<1.962200<2.2504)$. Dengan demikian dapat disimpulkan tidak terjadi masalah autokorelasi dalam model regresi sehingga model ini layak digunakan untuk analisis selanjutnya. 


\section{Hasil Uji Statistik Deskriptif}

Tabel 5. Uji Statistik Deskriptif

\begin{tabular}{|l|c|c|c|c|}
\hline \hline & $\begin{array}{c}\text { Penghindaran } \\
\text { Pajak }\end{array}$ & Karakter Eksekutif & $\begin{array}{c}\text { Kompensasi Rugi } \\
\text { Fiskal }\end{array}$ & Capital Intensity \\
\hline \hline Mean & 0.269148 & 0.058344 & 0.226087 & 0.363038 \\
\hline Median & 0.251335 & 0.041205 & 0.000000 & 0.351862 \\
\hline Maximum & 0.962060 & 0.458437 & 1.000000 & 0.634074 \\
\hline Minimum & 0.032015 & 0.003312 & 0.000000 & 0.128888 \\
\hline Std. Dev. & 0.114194 & 0.062801 & 0.420127 & 0.132427 \\
\hline Skewness & 3.614502 & 3.063416 & 1.309661 & 0.009879 \\
\hline Kurtosis & 19.80883 & 16.72568 & 2.715212 & 1.919017 \\
\hline Jarque-Bera & 1604.227 & 1082.593 & 33.26352 & 5.601053 \\
\hline Probability & 0.000000 & 0.000000 & 0.000000 & 0.060778 \\
\hline Sum & 30.95203 & 6.709608 & 26.00000 & 41.74937 \\
\hline $\begin{array}{l}\text { Sum Sq. } \\
\text { Dev. }\end{array}$ & 1.486588 & 0.449615 & 20.12174 & 1.999217 \\
\hline Observations & 115 & 115 & 115 & 115 \\
\hline
\end{tabular}

Sumber: Data diolah dengan Eviews 10, 2021

Uji statistik deskriptif ini digunakan untuk mengetahui gambaran dari masingmasing variabel yang digunakan dalam penelitian. Dari penelitian tersebut dapat diketahui nilai minimum, maksimum, rata-rata (mean), standar deviasi, dan varian.

\section{Hasil Analisis Regresi Data Panel}

Tabel 6. Analisis Regresi Data Panel

\begin{tabular}{|c|c|c|c|c|}
\hline Variable & Coefficient & Std. Error & t-Statistic & Prob. \\
\hline $\mathrm{C}$ & 0.186745 & 0.071897 & 2.597387 & 0.0110 \\
\hline Karakter Eksekutif & -0.243188 & 0.221275 & -1.099032 & 0.2747 \\
\hline Kompensasi Rugi Fiskal & 0.298809 & 0.071574 & 4.174849 & 0.0001 \\
\hline Capital Intensity & 0.079976 & 0.205595 & 0.388998 & 0.6982 \\
\hline \multicolumn{5}{|c|}{ Effects Specification } \\
\hline \multicolumn{5}{|c|}{ Cross-section fixed (dummy variables) } \\
\hline R-squared & 0.525571 & \multirow{7}{*}{\multicolumn{2}{|c|}{$\begin{array}{l}\text { Mean dependent var } \\
\text { S.D. dependent var } \\
\text { Akaike info criterion } \\
\text { Schwarz criterion } \\
\text { Hannan-Quinn criter. } \\
\text { Durbin-Watson stat }\end{array}$}} & 0.269148 \\
\hline Adjusted R-squared & 0.392304 & & & 0.114194 \\
\hline S.E. of regression & 0.089020 & & & -1.804040 \\
\hline Sum squared resid & 0.705281 & & & -1.183447 \\
\hline Log likelihood & 129.7323 & & & -1.552145 \\
\hline F-statistic & 3.943755 & & & 1.523117 \\
\hline Prob(F-statistic) & 0.000001 & & & \\
\hline
\end{tabular}

Sumber: Data diolah dengan Eviews 10, 2021

Berdasarkan hasil pengujian pada tabel di atas maka persamaan linier yang digunakan dalam penelitian ini dengan variabel dependen penghindaran pajak sebagai berikut:

$$
Y=0.186745-0.243188\left(X_{1}\right)+0.298809\left(X_{2}\right)+0.079976\left(X_{3}\right)+\mu
$$


Dari hasil persamaan linier di atas yang digunakan dalam penelitian ini dapat dijelaskan sebagai berikut: (1) Nilai koefisien konstanta sebesar 0.186745 artinya jika variabel karakter eksekutif, kompensasi rugi fiskal dan capital intensity dianggap konstan, maka hasil penghindaran pajak sebesar 0.186745. (2) Koefisien karakter eksekutif sebesar 0.243188 artinya setiap peningkatan karakter eksekutif sebesar 1 satuan, maka akan menurunkan variabel penghindaran pajak sebesar -0.243188 dengan asumsi variabel independen lain nilainya tetap. (3) Koefisien kompensasi rugi fiskal sebesar 0.298809 artinya setiap peningkatan kompensasi rugi fiskal sebesar 1 satuan, maka akan meningkatkan variabel penghindaran pajak sebesar 0.298809 dengan asumsi variabel independen lain nilainya tetap. (4) Koefisien capital intensity sebesar 0.079976 artinya setiap peningkatan capital intensity sebesar 1 satuan, maka akan meningkatkan variabel penghindaran pajak sebesar 0.079976 dengan asumsi variabel independen lain nilainya tetap.

\section{Hasil Uji Hipotesis}

\section{Uji Signifikansi Parsial (Uji t)}

Tabel 7. Uji Signifikansi Parsial (Uji t)

\begin{tabular}{crrrr}
\hline \hline Variable & Coefficient & Std. Error & t-Statistic & Prob. \\
\hline \hline C & 0.186745 & 0.071897 & 2.597387 & 0.0110 \\
Karakter Eksekutif & -0.243188 & 0.221275 & -1.099032 & 0.2747 \\
Kompensasi Rugi Fiskal & 0.298809 & 0.071574 & 4.174849 & 0.0001 \\
Capital Intensity & 0.079976 & 0.205595 & 0.388998 & 0.6982 \\
\hline \hline
\end{tabular}

Sumber: Data diolah dengan Eviews 10, 2021

Hasil Uji t nilai signifikan karakter eksekutif terhadap penghindaran pajak adalah $0.2747>0,05$ dengan nilai $t$ hitung lebih kecil dari t tabel $(-1.0990<-1.9816)$ yang berarti bahwa karakter eksekutif tidak berpengaruh terhadap Penghindaran Pajak. Maka disimpulkan bahwa $\mathrm{H} 2$ ditolak, yaitu karakter eksekutif tidak berpengaruh terhadap penghindaran pajak pada perusahaan industri barang konsumsi yang terdaftar pada periode 2016-2020. Hasil penelitian ini mendukung penelitian Radiansyah \& Nofrayanti (2015), Bobby (2017) dan Kusumastuti (2018) yang menyatakan apabila eksekutif semakin bersifat risk averse maka eksekutif tersebut tidak akan melakukan tindakan Penghindaran Pajak. Besar kecilnya risiko perusahaan mengindikasikan bahwa pimpinan perusahaan lebih bersifat risk taker yang lebih berani mengambil risiko. Sebaliknya tingkat risiko yang kecil mengindikasikan bahwa pimpinan perusahaan lebih bersifat risk averse yang cenderung untuk menghindari risiko. Hasil penelitian ini bertolak belakang 
dengan penelitian Merkusiwati dan Damayanthi (2019), Sopyanto (2018), Kori (2017), yang menyatakan bahwa karakter eksekutif berpengaruh signifikan terhadap penghindaran pajak.

Hasil Uji t nilai signifikan Kompensasi Rugi Fiskal terhadap Penghindaran Pajak adalah 0,0001 < 0,05 dengan nilai T hitung lebih besar dari t tabel $(4.1748>1.9816)$ yang berarti bahwa Kompensasi Rugi Fiskal berpengaruh terhadap Penghindaran Pajak. Nilai koefisien regresi pada variabel Kompensasi Rugi Fiskal sebesar 0.298809 yang menandakan bahwa Kompensasi Rugi Fiskal memiliki hubungan positif. Maka disimpulkan bahwa H2 diterima, yaitu Kompensasi Rugi Fiskal berpengaruh signifikan terhadap Penghindaran Pajak pada perusahaan industri barang konsumsi yang terdaftar pada periode 2016-2020. Hasil penelitian ini mendukung penelitian Ginting (2016) yang menjelaskan bahwa kompensasi rugi fiskal berpengaruh signifikan terhadap penghindaran pajak bahwa kerugian yang dialami perusahaan dapat dikompensasikan selama 5 tahun ke depan. Dan juga menurut Arini (2017) Perusahaan yang memiliki kompensasi rugi fiskal di tahun t maka tentu saja itu akan mengurangi beban pajaknya pada tahun tersebut, dan itu menjadi kesempatan bagi perusahaan untuk melakukan penghindaran pajak. Hasil penelitian ini bertolak belakang dengan penelitian Humairoh dan Triyanto (2019), Setiawan (2019), Sundari dan Aprilina (2017) yang menyatakan bahwa komepensasi rugi fiskal tidak memiliki pengaruh terhadap penghindaran pajak.

Hasil Uji t nilai signifikan Capital Intensty terhadap Penghindaran Pajak adalah $0.6982>0,05$ dengan nilai T hitung lebih kecil dari tabel $(0.3889<1.9816)$ yang berarti bahwa Capital Intensity tidak berpengaruh terhadap Penghindaran Pajak. Hasil penelitian ini mendukung penelitian Merkusiwati (2019) dan Sopyanto (2018) yang menyatakan bahwa invetasi aktiva tetap tidak berpengaruh signifikan terhadap penghindaran pajak. Perusahaan yang memiliki aset tetap yang besar bukan digunakan perusahaan sebagai pengurang pajak karena biaya penyusutan yang melekat pada asset tetap, melainkan untuk menunjang kegiatan operasional perusahaan. Hasil penelitian ini bertolak belakang dengan penelitian Pranyoto (2017) dan Humairoh dan Triyanto (2019), yang menyatakan bahwa investasi aktiva tetap berpengaruh signifikan terhadap penghindran pajak. Semakin besar intensitas aset tetap maka effective tax rate perusahaan semakin rendah atau tingkat penghindaran pajak perusahaan semakin besar. 


\section{Uji Signifikansi Simultan (Uji F)}

Tabel 8. Uji Signifikansi Simultan (Uji F)

\begin{tabular}{llll}
\hline \hline F-statistic & 3.943755 & Durbin-Watson stat & 1.523117 \\
Prob(F-statistic) & 0.000001 & & \\
\hline \hline
\end{tabular}

Sumber: Data diolah dengan Eviews 10, 2021

Hasil uji signifikansi simultan pada tabel di atas diketahui hasil yang diperoleh dari uji F statistik menunjukan bahwa F-statistik sebesar 3.943755 dengan df $1(k-1)(4-1)=$ 3 dan df $2(n-4)=115-4=111$ maka diperoleh hasil untuk $F$ tabel sebesar 2,69. Jadi $F$ hitung lebih besar dari $\mathrm{F}$ tabel atau $3.943755>2,69$ dan nilai probabilitas $\mathrm{F}$ sebesar $0,000001<0,05$. Dapat ditarik kesimpulan bahwa karakter eksekutif, kompensasi rugi fiskal dan capital intensity berpengaruh terhadap penghindaran pajak secara simultan.

\section{Hasil Uji Koefisien Determinasi}

Tabel 9. Uji Koefisien Determinasi

\begin{tabular}{llll}
\hline \hline R-squared & 0.525571 & Mean dependent var & 0.269148 \\
Adjusted R-squared & 0.392304 & S.D. dependent var & 0.114194 \\
\hline \hline
\end{tabular}

Sumber: Data diolah dengan Eviews 10, 2021

Nilai Adjusted $R$-Squared adalah sebesar 0.392304 yang berarti bahwa variasi perubahan naik turunnya penghindaran pajak dapat dijelaskan oleh karakter eksekutif (X1), kompensasi rugi fiskal (X2) dan capital intensity (X3) sebesar 39\%. Sementara sisanya yaitu sebesar $61 \%$ dijelaskan oleh variabel-variabel lain yang tidak diteliti dalam penelitian ini.

\section{KESIMPULAN}

Berdasarkan hasil dan pembahasan penelitian yang telah dilakukan, maka kesimpulan dari penelitian ini adalah sebagai berikut: (1) Hasil penelitian karakter eksekutif, kompensasi rugi fiskal dan capital intensity terhadap penghindaran pajak dapat disimpulkan $\mathrm{H} 1$ diterima karena berpengaruh secara bersamaan (simultan). (2) Hasil penelitian karakter eksekutif dapat disimpulkan $\mathrm{H} 2$ ditolak karena tidak berpengaruh terhadap penghindaran pajak. (3) Hasil penelitian kompensasi rugi fiskal dapat disimpulkan H3 diterima karena berpengaruh terhadap penghindaran pajak. (4) Hasil penelitian capital intensity dapat disimpulkan ditolak karena tidak berpengaruh terhadap penghindaran pajak. 


\section{Saran}

Berdasarkan hasil dari kesimpulan diatas, adapun saran yang dapat diberikan antara lain: (1) Bagi masyarakat yang ingin meneliti variabel penghindaran pajak diharapkan untuk menambahkan variabel-variabel independen lain yang secara teoritis lebih berpengaruh terhadap penghindaran pajak. Hal ini dikarenakan variabel dalam penelitian ini masih belum memberikan hasil secara menyulur tetang penghindaran pajak. (2) Bagi universitas untuk mahasiswa diharapkan memperluas objek penelitian yang akan digunaka. Salah satunya dengan cara menambah sampel yang digunakan bukan hanya sekedar perusahaan sektor industri barang konsumsi yang terdaftar di Bursa Efek Indonesia, namun bisa juga menggunakan objek lain seperti sektor pertanian, sektor pertambangan, sektor industri dasar dan kimia, sektor aneka industri, sektor properti, sektor infrastruktur, sektor finansial, dan sektor perdagangan. (3) Bagi pemerintah sebaiknya dilakukan pengawasan yang lebih mengenai kegiatan penghindaran pajak yang dilakukan oleh perusahaan agar sesuai dengan undangundang, dan upaya tersebut semata-mata masih dalam batas kegiatan bisnis yang baik.

\section{DAFTAR PUSTAKA}

Annisa, M. (2018, Februari 08). Chairman Samsung Jadi Tersangka Penghindaran Pajak Rp102 Miliar. Retrieved from KABAR24: https://kabar24.bisnis.com/read/20180208/19/736313/cha-samsung-jaditersangka-penghindaran-pajak-rp102-miliar

Arini. (2017). Pengaruh Corporate Governance, Ukuran Perusahaan Dan Kompensasi Rugi Fiskal Terhadap Tax Avoidance. Skripsi, Universitas Pamulang; Tangerang Selatan.

Baskoro, F. M. (2016, September 23). Bukan Hanya di Indonesia, Google Juga Hindari Pajak di Eropa. Retrieved from BERITA SATU: https://www.beritasatu.com/dunia/387930/bukan-hanya-di-indonesia-googlejuga-hindari-pajak-di-eropa

Bobby, N. (2017). Karakteristik Eksekutif, Intensitas Modal dan Corporate Social Responsibility (CSR) terhadap Tax avoidance. Skripsi, Universitas Pamulang; Tangerang Selatan.

Firman, G. (2017). Pengaruh Kepemilikan Institusional, Capital Intensity dan Ukuran Perusahaan terhadap Tax Avoidance. Skripsi, Universitas Pamulang; Tangerang Selatan.

Geminastiti. (2017). Pengaruh Good Corporate Governance Dan Karakteristik Eksekutif Terhadap Tax Avoidance. Skripsi, Universitas Pamulang; Tangerang Selatan.

Ginting, S. (2016). Pengaruh Corporate Governance Dan Kompensasi Rugi Fiskal Terhadap Penghindaran Pajak Dengan Ukuran Perusahaan Sebagai Variabel Moderating. Jurnal Wira Ekonomi Mikroskil, 6(2), 167-168. 
Humairoh, N. R., \& Triyanto, D. N. (2019). Pengaruh ROA, Kompensasi Rugi Fiskal Dan Capital Intensity terhadap Tax Avoidance. Jurnal Akuntansi, Audit dan Sistem Informasi Akuntansi, 3(3), 335-348.

Irawati, W., \& Sari, A. K. (2019). Pengaruh Persepsi Wajib Pajak Dan Preferensi Risiko Terhadap Kepatuhan Wajib Pajak. Jurnal Akuntansi Barelang, 3(2), 104-114.

Jensen, M. C., \& Meckling, W. H. (1976). Theory of the firm: Managerial behavior, agency costs and ownership structure. Journal of Financial Economics, 3 (4), 305-360.

Kemenperin. (n.d.). Manufaktur Ditopang Sektor Barang Konsumsi. Retrieved from Kementerian Perindustrian Republik Indonesia:https://www.kemenperin.go.id/ artikel/7014/Manufaktur-Ditopang-Sektor-Barang-Konsumsi

Kontan.co.id. (2019). Kontan.Co.Id. Retrieved from Tax Justice laporkan Bentoel lakukan penghindaran pajak: https://nasional.kontan.co.id/news/tax-justice-laporkanbentoel-lakukan-penghindaran-pajak-indonesia-rugi-rp-14-juta

Kusumastuti, M. T. (2018). Pengaruh Corporate Governance, Karakter Eksekutif, Insentif Eksekutif Dan Leverage Terhadap Tax Avoidance. Prosiding Seminar Nasional: Manajemen, Akuntansi, Dan Perbankan, 1(1), 769-780.

Lerid, F., Sianturi, F., \& Pratomo, D. (2020). Pengaruh Karakter Eksekutif, Gender Diversity Eksekuti Dan Insentif Eksekutif terhadap Tax Avoidance. e-Proceeding of Management, 7(2), 2945-2952.

Luayyi, S. (2010). Teori Keagenan Dan Manajemen Laba Dari Sudut Pandang Etika Manajer. El Muhasaba Jurnal Akuntansi, 1(2), 199-216.

Maisyaroh, S. (2016). Pengaruh Karakter Eksekutif Dan Intensitas Modal Terhadap Tax Avoidance. Skripsi, Universitas Pamulang;Tangerang Selatan.

Malinda, K. P. (2017). Pengaruh Karakter Eksekutif Dan Good Corporate Governance Terhadap Tax Avoidance. Skripsi, Universitas Pamulang; Tangerang Selatan.

Merkusiwati, N. A., \& Damayanthi, I. E. (2019). Pengaruh Pengungkapan CSR, Karakter Eksekutif dan Investasi Aktiva Tetap Terhadap Penghindaran Pajak . E-JA : eJurnal Akuntansi, 29(2), 833-853.

Pajak.go.id. (n.d.). Pajak. Retrieved Januari 2021, from Kementerian Keuangan Direktorat Jendral Pajak: https://www.pajak.go.id/pajak

Pohan, C. A. (2017). Manajemen Perpajakan Strategi Perencanaan Pajak dan Bisnis Edisi Revisi. Jakarta: PT Gramedia Jakarta.

Pranyoto. (2017). Pengaruh Corporate Social Responsibility Dan Capital Intensity Terhadap Penghindaran Pajak. Skripsi, Universitas Pamulang; Tangerang Selatan.

Putri, N. R., \& Irawati, W. (2019). Pengaruh Kepemilikan Manajerial dan Effective Tax Rate terhadap Kebijakan Dividen dengan Likuiditas sebagai Variabel Moderating. Jurnal Kajian Akuntansi, 3(1), 93-108.

Radiansyah, \& Nofrayanti. (2015). Pengaruh Karakter Eksekutif Dan Karakteristik Perusahaan Terhadap Penghindaran Pajak (Tax avoidance). Jurnal Ilmiah Akuntansi Universitas Pamulang, 3(2), 782-816.

Setiawan, Y. (2019). Pengaruh Intensitas Modal, Kualitas Audit dan Kompensasi Rugi Fiskal terhadap Tax Avoidabce. Skripsi, Universitas Pamulang; Tangerang Selatan. 
Sopyanto. (2018). Pengaruh Corporate Social Resposibility, Capital Intensity Dan Karakteristik Eksekutif Terhadap Tax Avoidance. Skripsi, Universitas Pamulang; Tangerang Selatan.

Sugiarto. (2019). Pengaruh Koneksi Politik, Risiko Perusahaan, Dan Capital Intensity Terhadap Penghindaran Pajak . Skripsi, Universitas Pamulang; Tangerang Selatan.

Sugiyono. (2017). Metode Penelitian Kuantitatif, Kualitatif, dan R\&D. Bandung: Alfabeta.

Sundari, N., \& Aprilina, V. (2017). Pengaruh konservatisme akuntansi, Intensitas aset tetap, Kompensasi rugi fiskal dan corporate governance terhadap tax avoidance. JRAK: Jurnal Riset Akuntansi dan Komputerisasi Akuntansi, 8(2), 85-109.

Ulfa, V. (2018). Pengaruh Leverage, Ukuran Perusahaan dan Kualitas Audit Terhadap Penghindaran Pajak (Tax Avoidance). Skripsi thesis, Universitas Islam Negeri Sultan Syarif Kasim Riau.

Wiguna, I. P., \& Jati, I. K. (2017). Pengaruh Corporate Social Responsibility, Preferensi Risiko Eksekutif dan Capital Intensity Pada Penghindaran Pajak. E-Jurnal Akuntansi Universitas Udayana, 2(1), 418-446. 